\title{
HAKIKAT MEMBACA DAN IMPLIKASINYA BAGI PENGAJARAN
}

\author{
Oleh: Sugirin
}

Abstrak

Membaca merupakan kunci ilmu pengetahuan, maka wajar lah apabila pengembangan keterampilan membaca memerlukan perhatian para pendidik. Keterampilan membaca diperlukan bukan hanya oleh pelajar dan mahasiswa, melainkan juga oleh mereka yang sudah menjadi sarjana atau bahkan guru besar, yang masih ingin memperdalam atau memperluas pengetahuannya. Keterampilan membaca perlu dikembangkan, tetapi sebelumnya perlu dikaji hakikat mambaca itu sendiri agar usaha pengembangan bertolak dari sesuatu yang sudah dipahami. Tanpa memahami hakikat membaca, kiranya usaha pengembangan keterampilan membaca akan kurang terarah karena tidak dilandasi dengan pemahaman tentang apa yang harus dikembangkan.

Berbagai pengertian membaca dan hal-hal yang menyiratkan makna membaca dikaji. Dari kajian tersebut dihasilkan hakikat membaca sebagai berikut: (1) hakikat mikro, yaitu membaca dengan makna terbatas, dengan membaca nyaring sebagai contohnya; (2) hakikat makro, membaca dengan makna yang sangat luas, yaitu membaca sebagai upaya memahami hidup dan kehidupan manusia dan alam dengan cara memperhatikan gejala-gejala yang tampak maupun yang tidak tampak tetapi diyakini adanya, misalnya membaca tanda-tanda kebesaran Allah; dan (3) hakikat umum (sedang), yaitu membaca dengan makna memanfaatkan segala daya (pengetahuan dan pengalaman) dan upaya (strategi dan taktik) untuk menafsirkan makna tulisan dan/atau lambang cetak, misalnya membaca buku metodologi penelitian.

Sebagai implikasinya, apabila membaca dipandang dari hakikat mikro, pengajaran membaca berarti melatih pembelajar untuk dapat melafalkan atau mengucapkan tulisan atau lambang cetak. Berdasarkan hakikat makro, pengajaran membaca mempunyai cakupan yang sangat luas, yaitu melatih pembelajar untuk memahami hidup dan kehidupan manusia dan alam sekitar melalui pemahaman terhadap gejala-gejala yang tampak maupun yang tidak tampak, dengan tujuan agar dapat berbuat yang terbaik demi kesejahteraan hidup di dunia maupun di akhirat. Dengan berpegang pada hakikat umum, pengajaran membaca berarti memberikan kesempatan kepada pembelajar untuk berlatih memanfaatkan segala daya (pengetahuan dan pengalaman) dan upaya (strategi dan taktik) untuk memahami makna tulisan dan/atau lambang cetak sesuai maksud penulisnya.

\section{A. Pendahuluan}

Sering kita dengar ibu-ibu yang mengatakan anaknya sudah pandai 
membaca karena dapat melafalkan tulisan "i-ni i-bu bu-di." Begitu pula jamaah pengajian terkagum-kagum dengan anak usia delapan tahun yang telah dapat membaca Al-Qur'an dengan fasih di hadapan umum. Namun ada juga dosen yang mengeluhkan adanya mahasiswa Jurusan Pendidikan Bahasa Inggris (dari kelompok yang mestinya telah mahir membaca) yang belum dapat membaca buku berbahasa Inggris karena hasil tugas meringkas isi buku tidak seperti yang diharapkan. Masih ada beberapa contoh lain yang berkaitan dengan masalah membaca. Misalnya, seorang pengendara sepeda motor yang melintasi perempatan ketika lampu merah menyala ditangkap polisi karena tidak dapat membaca rambu lalu lintas. Pada era globalisasi ini pengusaha yang tidak pandai membaca peluang pasar pasti akan gulung tikar. Selain itu masih banyak lagi pengertian membaca yang dikaitkan dengan masalah yang lebih luas atau mendalam seperti keprihatian orang-orang bijak yang membaca peristiwa atau gejolak akhir-akhir ini sebagai tanda makin tuanya zaman. Begitu pula para pendakwah agama selalu menyampaikan himbauan kepada umat untuk pandai-pandai membaca tanda-tanda kebesaran Allah.

Dengan adanya beberapa contoh penggunaan kata membaca yang dikaitkan dengan berbagai kejadian dan gejala tersebut di atas, permasalahan yang perlu dijawab adalah: (1) Apa hakikat membaca? dan (2) Bagaimana implikasinya bagi pengajaran?

\section{B. Hakikat Membaca}

Dari sederet contoh di atas, paling tidak ada tiga hal yang dapat ditangkap berkaitan dengan makna membaca menurut versi penuturnya. Pertama, dari kasus "i-ni i-bu bu-di" dan anak yang fasih membaca Al-Qur'an jelas sekali bahwa yang dimaksud membaca adalah melafalkan tulisan. Seorang ibu mengatakan anaknya pandai membaca karena anak tersebut sudah dapat mengucapkan "i-ni i-bu bu-di". Mungkin sekali dia bisa mengucapkannya karena ingat apa yang dikatakan orang lain atau memang sudah mengenal rangkaian huruf. Namun kemungkinan besar dia tidak tahu arti yang diucapkannya kecuali dengan penjelasan orang lain melalui gambar yang menyertainya. Begitu pula kekaguman jamaah terhadap anak yang fasih melantunkan ayat-ayat $\mathrm{Al}$ Qur'an adalah kekaguman terhadap pengucapannya, belum menyangkut pemahamannya. Kedua, dari membaca tanda-tanda zaman dan membaca tanda-tanda kebesaran Allah, membaca dimaksudkan menggunakan segenap potensi jiwa dan raga yang ada pada diri manusia termasuk indera, akal, perasaan, iman dan kemauan untuk memperhatikan 
ciptaan-ciptaan Allah baik yang tampak maupun yang tidak tampak agar dapat memahami hakikat hidup dan kehidupan manusia dan alam sekitar. Tujuannya tentunya agar manusia dapat berbuat yang terbaik sesuai dengan hakikat dirinya. Ketiga, dari keluhan dosen tentang mahasiswanya, makna membaca adalah memahami isi buku sesuai dengan yang dimaksud oleh penulisnya (paling tidak maksud penulis menurut penafsiran dosen tersebut), sehingga mahasiswa dapat membuat ringkasan isinya secara memadai. Selanjutnya kiranya perlu dikaji berbagai pendapat tentang membaca yang berhubungan dengan ketiga contoh makna tersebut di atas.

Smith (1985:100) mengatakan bahwa seperti halnya kata-kata lain pada umumnya, reading (membaca) mempunyai lebih däri satu makna; membaca kadang-kadang berakibat atau mencerminkan pemahaman dan kadang-kadang tidak. Kasus pertama di atas, anak yang dapat mengucapkan "i-ni i-bu bu-di", kiranya termasuk yang tidak mencerminkan pemahaman. Menurut Smith (1985:102) makna membaca seperti dalam kasus ini merupakan salah satu jawaban yang paling umum diberikan apabila orang ditanya arti membaca - the decoding of written words into sound (melafalkan atau menyuarakan kata-kata yang tertulis) atau sering disebut membaca nyaring (reading aloud). Hood \& Solomon (1985:125) mengakui bahwa dalam pengajaran bahasa Inggris sebagai bahasa lain (selain bahasa ibu) reading aloud merupakan kegiatan yang banyak dipraktikkan di dalam kelas. Bahkan dikatakan ada guru yang menganggap bahwa siswa yang dapat membaca nyaring dengan baik adalah pembaca yang baik. Benarkah begitu? Dengan pemberian teori secara baik dan latihan yang cukup, guru dapat membuat siswa mahir mengucapkan kata, frase, atau kalimat tanpa harus tahu artinya. Penulis sendiri dapat dengan benar mengucapkan kata-kata dalam bahasa Inggris yang belum pernah digunakannya, tetapi kalau ditanya artinya mungkin banyak yang tidak diketahuinya. Kiranya benar yang dikatakan oleh Hood \& Solomon bahwa reading aloud merupakan keterampilan yang terlepas dari membaca untuk memahami makna. Ditinjau dari makna membaca kategori ketiga di atas, reading aloud tidak baik karena terlalu menekankan pada pengucapan, memperlambat kegiatan membaca dan mengganggu pemahaman (Hood \& Solomon, 1985:126). Bahkan kalau membaca nyaring atau vokalisasi dilakukan pada saat pembaca membaca dalam hati (silent reading) Zuchdi (1991:11) menganggapnya sebagai kebiasaan yang tidak baik dengan alasan seperti yang dikemukakan Hood \& Solomon tersebut di atas. Ini bukan berarti bahwa reading aloud tidak ada gunanya. 
Untuk tujuan-tujuan tertentu reading aloud sangat bermanfaat, misalnya (bagi guru) untuk mengecek ucapan dan memantau pemahaman melalui cara pembaca memenggal kalimat, memantau strategi membaca yang digunakan, misalnya apakah terjadi regresi atau membaca ulang, dsb. Dalam. dunia seni baca Al Qur'an, seni baca puisi, seni pidato dan seni suara, membaca nyaring maupun vokalisasi mempunyai kedudukan yang sangat penting. Di sini tentu saja kegiatan membaca nyaring berbeda dengan membaca nyaring pada kasus "i-ni i-bu bu-di". Dalam seni pidato, misalnya, isi teks dipahami dan dihayati terlebih dahulu baru kemudian dibaca nyaring. Sementara dalam kasus "i-ni i-bu bu-di" kemungkinan besar si anak tidak atau belum memahami maksudnya (kecuali apabila tulisan itu disertai gambar dan dijelaskan oleh orang lain).

Membaca dengan makna kedua tidak selalu berhubungan dengan tulisan atau lambang visual yang jelas, tetapi terkait erat dengan pemahaman. Ungkapan membaca peluang pada judul Sukses Pengusaha Kecil, Jeli Membaca Peluang (Jawa Pos, 12 Oktober 1996 halaman 14) ternyata makna membaca adalah memahami apa sebenarnya yang diinginkan oleh pasar. Secara lebih rinci dijelaskan bahwa maksud membaca peluang adalah melakukan pengamatan untuk memahami situasi pasar agar dengan tepat dapat mengambil keputusan tentang apa yang akan diproduksi, cara produksi, cara distribusi, dsb. Misalnya, pengusaha kecil harus membuat model sesuai kemauan pembeli dan kalau perlu menggunakan beberapa merek untuk produk perusahaan yang sama. Dalam pengamatan pun pengusaha tidak sekedar melihat orang berjualan atau orang berbelanja, tetapi juga mendengarkan omongan pembeli, sopir pengangkut barang, ibu-ibu rumah tangga, dsb. Dalam hal ini kecil sekali kemungkinan keterlibatan tulisan yang secara langsung dapat dilihat dalam pengamatan.

Begitu pula dengan contoh yang lain. Dalam bahasa agama dikatakan bahwa dalam mengarungi kehidupan manusia diperintahkan senantiasa membaca tanda-tanda kebesaran Allah. Dalam Al Qur'an Surat Al Baqarah ayat 164 (Departemen Agama RI, 1984:40) Allah berfirman: Sesungguhnya dalam penciptaan langit dan bumi, silih bergantinya malam dan siang, bahtera yang berlayar di laut membawa apa yang berguna bagi manusia, dan apa yang Allah turunkan dari langit berupa air, lalu dengan air itu Dia hidupkan bumi sesudah mati (kering)-nya, dan Dia sebarkan di bumi itu segala jenis hewan, dan pengisaran angin dan awan yang dikendalikan antara langit dan bumi; sungguh (terdapat) tanda-tanda (kebesaran Allah) bagi kaum yang mau 
berpikir. Dalam hal ini membaca bukan sekedar melihat tulisan, buku-buku agama atau buku ilmu pengetahuan, melainkan memperhatikan semua ciptaan Allah baik yang tampak (bumi, air, hewan, dsb.) maupun yang tidak tampak (misalnya pengisaran angin). Bagi manusia Indonesia yang ber-Ketuhanan Yang Mahaesa, mengenal kehidupan dunia dan akhirat, kiranya hal ini tidak sulit dipahami. Di dunia perguruan tinggi, di dalam kehidupan akademik, membaca tanda-tanda kebesaran Allah ini di antaranya diwujudkan dengan melakukan penelitian. Maka tidak mengherankan kalau di Britania Raya (Sinclair, 1995:1368) ada istilah reader yang artinya bukan sekedar pembaca melainkan jabatan dosen senior di perguruan tinggi satu tingkat di bawah profesor (di Indonesia kira-kira setingkat dengan jabatan Lektor Utama Madya), yang salah satu tugas utamanya adalah melakukan penelitian.

Selanjutnya, makna membaca kategori ketiga berkaitan dengan makna membaca yang menurut Smith (1985:100) merupakan kegiatan membaca yang berakibat atau mencerminkan pemahaman. Beberapa makna yang dimaksud antara lain adalah: understanding print (memahami tulisan), understanding the author's thoughts (memahami pikiran penulis), getting questions answered (upaya mendapatkan jawaban atas pertanyaan), dan extracting information from text (menyarikan informasi dari teks),

Pengertian understanding print tampaknya bersifat umum pemahaman tulisan pada umumnya, sementara understanding the author's thoughts dapat dirasakan sewaktu kita membaca surat. Pada saat membaca surat kita ingin memahami pikiran penulis surat atau menangkap pesan penulis yang disampaikan lewat surat tersebut. Getting questions answered dilakukan misalnya oleh peserta tes membaca terhadap teks yang disertai pertanyaan. Peserta tes membaca teks karena ingin memperoleh informasi untuk menjawab pertanyaan. Contoh yang lain misalnya peserta UMPTN (Ujian Masuk Perguruan Tinggi Negeri) membaca koran pada hari pengumuman hasil UMPTN karena ingin tahu apakah dia lulus dan diterima di PTN yang diinginkan. Extracting information from texts mengandung arti seperti yang diharapkan oleh dosen yang mengeluhkan mahasiswanya yang belum dapat membaca buku berbahasa Inggris karena hasil tugas meringkas isi buku tidak atau belum seperti yang diharapkan. Dosen ini tentunya berharap bahwa mahasiswa dapat memahami intisari informasi yang terkandung dalam buku yang dibuktikan dengan ringkasan isi buku yang cukup memadai, sesuai atau setidak-tidaknya mendekati isi atau maksud buku yang sebenarnya. Dalam bahasa Al Qur'an, membaca Al Kitab dengan bacaan yang sebenarnya adalah 
tidak mengubah dan menta'wilkan Al Kitab sekehendak hatinya sendiri, artinya harus sesuai dengan yang dimaksud oleh Pemberi wahyu Al Qur'an itu sendiri (Departemen Agama RI, 1984:32). Kalau ringkasan isi buku yang dibuat mahasiswa masih belum mencerminkan isi buku yang dibaca, hal ini tentunya karena kemampuan pemahaman yang belum memadai. Karena makna membaca kategori ketiga ini tampaknya lebih menyentuh makna yang biasa dikenal oleh pembaca tulisan ini pada umumnya, maka perlu kiranya dikaji lebih lanjut pendapat-pendapat yang berhubungan dengan makna membaca kategori ini.

Makna membaca yang telah diuraikan di atas erat kaitannya dengan tujuan membaca. Selain ditinjau dari tujuan makna membaca dapat pula dikaji dari prosesnya. Menurut Taylor \& Taylor (1983:116) semua proses membaca dimulai dengan semacam ekstraksi lambang visual. Proses ini identik dengan ekstraksi lambang visual yang digunakan oleh manusia dalam memperoleh persepsi pada umumnya. Pada tahap awal pengamatan terhadap sesuatu bentuk luar dipandang lebih penting daripada keadaan di dalam yang rumit, karena manusia biasanya cenderung melihat objek dari luar ke dalam. Namun informasi dari lambang visual tidak cukup bagi kepentingan pemahaman. Smith (1985:35) mengatakan bahwa membaca lebih banyak bergantung pada apa yang ada di balik mata - informasi non-visual (pengetahuan dan pengalaman pembaca yang berhubungan dengan masalah yang ditampilkan oleh lambang visual). Garner (1980:55), Goodman et al. (1987:210), Irwin \& Baker (1989:8) dan Meyer \& Keefe (1990:6-7) bahkan menegaskan bahwa latar belakang pengalaman atau pengetahuan mempunyai peran yang begitu penting sehingga tanpa pengalaman atau pengetahuan tentang masalah yang dibahas dalam wacana, pemahaman tidak akan terjadi. Namun Fyfe \& Mitchell (1985:166) mengingatkan bahwa pembaca yang baik adalah pembaca yang dapat menjaga keseimbangan antara kedua sumber informasi: informasi yang terdapat dalam wacana dan informasi di luar wacana, yaitu pengalaman dan pengetahuan untuk menafsirkan informasi tersebut.

Flesh (1949:182, dikutip dalam Taylor \& Taylor, 1983:117) menyatakan bahwa membaca itu merupakan suatu keajaiban. Mata pembaca menangkap kelompok-kelompok kata dalam waktu yang sangat singkat dan pikiran pembaca mengolah kata-kata ini dengan berbagai pertimbangan (pengetahuan, pengalaman, logika, dsb.) sehingga dicapai suatu pengertian yang masuk akal. Dikatakan pula bahwa apapun naskah yang dibaca, tujuannya sama - memahami isi dan menyimpan/mengingat intinya. 
Selanjutnya dalam penjelasan tentang proses membaca, atau secara lebih khusus tentang strategi pemahaman yang digunakan oleh pembaca, Burnes dan Page (1985:37-9) menyatakan bahwa proses membaca dimulai dengan membaca sebagian teks untuk dihubungkan dengan informasi nonvisual yang dimiliki oleh pembaca (sampling). Banyak sedikitnya bagian teks yang akan dibaca dalam tahap sampling tentunya tergantung pada berbagai faktor termasuk seberapa pengetahuan dan pengalaman yang dimiliki pembaca tentang masalahnya, format penyajiannya, kosakata yang digunakan, gaya penulisan serta kejelasan ilustrasinya. Setelah sekilas melihat sebagian teks pada tahap sampling, pembaca akan dapat meramalkan isi (predicting). Seperti dikatakan Goodman (1976:126), membaca merupakan psycholinguistic guessing game - proses pemilihan serangkaian informasi yang relevan yang tersimpan dalam ingatan jangka panjang dan pemanfaatannya sebagai dasar meramalkan atau menebak isi wacana yang dihadapi pembaca. Proses meramal atau menebak tidak berhenti pada awal membaca saja, tetapi berlanjut dengan diperolehnya tambahan informasi pada bagian teks selanjutnya. Apabila informasi selanjutnya sesuai dengan ramalan awal, maka terjadilah proses pembenaran terhadap ramalan tadi (confirming); sebaliknya kalau informasi berikutnya tidak sesuai ramalan, akan terjadi penolakan (rejecting). Apabila yang terjadi rejecting, maka pembaca akan berusaha melakukan koreksi (correcting) atau pembenahan (refining). Proses ini akan dapat dipantau secara jelas apabila pembaca membaca wacana secara nyaring, misalnya apakah pembaca membaca terus, apakah terjadi keraguan, apakah membaca ulang bagian-bagian tertentu, dsb.

Selain itu Goodman \& Burke (1980:1) mengatakan bahwa membaca merupakan interaksi antara pembaca dengan bahasa tulis dalam usaha pembaca menyusun kembali pesan penulis. Ini sejalan dengan pendapat Nuttal (1982:10) yang menyatakan bahwa membaca bukan sekedar proses aktif, melainkan juga interaktif. Makna diciptakan sendiri oleh pembaca dalam interaksinya dengan wacana. Menurut Widdowson (1984:91), pembaca bebas menghubungkan wacana dengan jalan pikirannya sendiri yang paling sesuai dengan tujuan membacanya. Karena itu Harri-Augstein \& Thomas (1984:278) menyatakan bahwa pembaca yang berbeda mungkin saja akan menafsirkan wacana yang sama dengan cara dan hasil yang berbeda. Ini bukan berarti bahwa dosen (dalam kasus mahasiswa belum dapat memahamai buku berbahasa Inggris) harus membebaskan mahasiswa untuk menafsirkan dan 
meringkas isi buku sekehendak hatinya sendiri dan memberikan nilai baik kepada semua yang telah menyerahkan tugas. Perbedaan persepsi dan penafsiran itu sangat mungkin, tetapi itulah yang harus dibenahi agar persepsi dan penafsiran mahasiswa mendekati maksud penulis.

Dari uraian tentang makna membaca kategori ketiga di atas dapat disimpulkan bahwa membaca merupakan proses interaksi antara pembaca dengan teks (lambang visual) dalam upaya pembaca untuk memahami informasi visual yang ada dalam teks dengan bantuan informasi non-visual (pengetahuan dan pengalaman pembaca) agar penafsiran terhadap teks sesuai dengan maksud penulisnya.

Selanjutnya ditilik dari keluasan kegiatan dan akibat atau hasilnya, tiga kategori makna membaca yang telah diuraikan tersebut di atas dapat dirumuskan menjadi tiga hakikat membaca: (1) hakikat mikro, yaitu membaca dengan makna terbatas, dengan membaca nyaring sebagai contohnya; (2) hakikat makro, yaitu membaca dengan makna yang sangat luas, misalnya membaca tanda-tanda kebesaran Allah; dan (3) hakikat umum (sedang): umum dengan pengertian bahwa makna ini merupakan makna yang lebih umum berlaku bagi kegiatan membaca sehari-hari, dan sedang dengan pengertian bahwa cakupan kegiatan yang dilakukan berada di antara keluasan kegiatan dalam hakikat mikro dan makro. Contoh kegiatan membaca menurut hakikat umum adalah membaca buku untuk dapat meringkas isinya. Perlu ditambahkan bahwa kegiatan dalam membaca menurut hakikat umum sering pula melibatkan kegiatan membaca menurut hakikat makro. Dalam membaca kitab suci dan bahkan karya sastra tertentu, hakikat makro akan banyak berperan. Oleh sebab itu hakikat makro dan hakikat umum bukanlah merupakan dua kawasan yang dibatasi dinding pemisah yang pasti, melainkan merupakan continuum, yaitu bahwa kegiatan membaca menurut hakikat umum kadang-kadang masuk pula ke kawasan membaca menurut hakikat makro. Selanjutnya bagaimana implikasi ketiga hakikat ini bagi pengajaran membaca?

\section{Implikasi Ketiga Membaca Bagi Pengajaran Membaca}

Pertama, dipandang dari hakikat mikro membaca adalah melafalkan atau mengucapkan tulisan. Dengan demikian pengajaran membaca akan banyak menyangkut pengajaran pronunciation, yang tujuannya adalah mengucapkan tulisan dengan ucapan yang benar. Untuk dapat mengucapkan tulisan dengan benar tentunya tidak cukup dengan menitikberatkan pada bunyi vokal atau konsonan secara individual, tetapi lebih ditekankan pada rangkaian 
bunyi yang digunakan dalam unit ujaran yang lebih luas: dialog, kalimat, frase dan kata. Kalau sudah masuk dalam ujaran, unsur-unsur segmental (misalnya: vokal, konsonan, dan diftong) secara individual menjadi tidak begitu penting diperhatikan. Yang akan lebih menentukan enak tidaknya suatu ujaran didengar atau mudah tidaknya ditangkap maknanya adalah unsur-unsur suprasegmental (misalnya: intonasi dan jeda). Dengan demikian penggunaan bunyi pada konteks yang lebih luas harus mendapatkan perhatian yang lebih besar. Di samping itu, ejaan menjadi bagian yang penting bagi pengajaran membaca menurut hakikat mikro karena dengan memperhatikan ejaan berbagai kata, dimungkinkan pembaca akan dapat mengucapkan kata-kata dengan ejaan serupa sekalipun kata-kata tersebut belum pernah dijumpainya.

Masalah yang mungkin akan dipertanyakan adalah: Perlukah kita mengajarkan membaca menurut hakikat mikro? Perlu dan tidaknya tentunya kembali kepada tujuan pengajaran membaca itu sendiri. Tujuan membaca bagi satu orang atau kelompok bisa saja berbeda dengan tujuan bagi orang atau kelompok lainnya. Bagi calon qori atau qoriah jelas hakikat mikro ini mutlak diperlukan, sementara bagi calon apoteker mungkin tidak perlu karena bagi calon apoteker yang penting adalah memahami bahwa tulisan/lambang tertentu mengacu pada jenis obat tertentu atau aturan tertentu. Bagi mahasiswa jurusan bahasa Inggris hal ini perlu asalkan tidak sampai menimbulkan kesan bahwa membaca nyaring merupakan inti pengajaran membaca pada umumnya.

Kedua, dipandang dari hakikat makro membaca adalah menggunakan segala potensi yang ada pada diri manusia termasuk panca indera, akal, perasaan, iman dan kemauan untuk menangkap gejala-gejala yang terjadi di masyarakat, tanda-tanda kehidupan alam, tanda-tanda zaman dan tanda-tanda lainnya yang menyiratkan tanda-tanda kebesaran Allah dengan cara memperhatikan ciptaan-ciptaanNya baik yang tampak terbentang di alam dunia maupun yang tidak tampak namun diyakini adanya. Dengan demikian pengajaran membaca dalam pengertian ini tidak cukup ditangani oleh guru atau dosen dalam pengajaran bahasa. Tokoh-tokoh lain seperti sastrawan, ekonom, filsuf, peneliti, pendakwah, alim-ulama, ahli kitab, dan ahli tafsir lebih banyak berperan dalam pengajaran membaca menurut hakikat makro. Dalam hal ini pengajaran membaca tidak sekedar membahas hal-hal yang berhubungan dengan baca tulis, tetapi lebih banyak menyangkut aspek-aspek kehidupan yang tidak secara langsung dapat diamati di dalam kelas. Dalam praktiknya pengajaran yang sangat terpadu seperti ini jarang atau bahkan tidak pernah dijumpai di dalam kelas. Yang mungkin terjadi adalah bahwa sebagian 
kegiatan membaca menurut hakikat makro ini dilakukan oleh tokoh-tokoh tersebut di atas dalam kapasitasnya sebagai pengajar. Seorang ekonom, misalnya, akan mengajarkan cara membaca peluang dalam merebut pasar; seorang pendakwah akan membeberkan cara membaca tingkah laku manusia atau situasi tertentu yang berpotensi membawa kejayaan atau kehancuran kehidupan beragama, dsb.

Ketiga, menurut hakikat umum, membaca merupakan proses interaksi antara pembaca dengan wacana (lambang visual) dalam upaya pembaca untuk memahami informasi visual yang ada dalam wacana dengan bantuan informasi non-visual (pengetahuan dan pengalaman pembaca) agar penafsiran terhadap wacana sesuai dengan maksud penulisnya. Dalam membimbing pembelajar, pengetahuan dan pengalaman pembelajar perlu diaktifkan untuk membantunya dalam memahami wacana yang dihadapi, karena seperti dikatakan Garner (1980:55), Goodman et al. (1987:210), Irwin \& Baker (1989:8) dan Meyer \& Keefe (1990:6-7) latar belakang pengalaman atau pengetahuan mempunyai peran yang begitu penting sehingga tanpa pengalaman atau pengetahuan tentang masalah yang dibahas dalam wacana, pemahaman tidak akan terjadi

Inilah pentingnya kegiatan pre-reading dalam pelajaran membaca. Kegiatan ini biasanya diisi dengan mencoba mengungkap pengetahuan dan pengalaman pembelajar yang berhubungan dengan wacana. Yang perlu dilatihkan adalah bagaimana pembelajar dapat memanfaatkan pengetahuan dan pengalaman itu untuk membantu tetapi jangan sampai menyesatkan pemahaman, sebab terlalu berpedoman pada apa yang telah diketahui tanpa memperhatikan apa yang tertulis akan menyesatkan pemahaman. Seperti diingatkan oleh Fyfe \& Mitchell (1985:166) bahwa pembaca yang baik adalah pembaca yang dapat menjaga keseimbangan antara kedua sumber informasi: informasi yang terdapat dalam wacana dan informasi di luar wacana, yaitu pengalaman dan pengetahuan untuk menafsirkan informasi dalam wacana tersebut.

Selanjutnya, dari uraian tentang proses membaca seperti yang dikemukakan di atas dapat dipetik pelajaran bahwa dalam pengajaran membaca pengajar hendaknya tidak hanya puas dengan hasil (produk) tetapi juga harus memperhatikan proses. Sebagai contoh, sekalipun pembelajar dapat menjawab pertanyaan bacaan dengan tepat, perlu ditelusuri proses yang dilakukan sampai pada jawaban tersebut. Salah satu cara menelusurinya ialah dengan mengajukan pertanyaan "Mengapa?" atau "Dari mana Anda tahu?" Dengan demikian pengajar akan tahu bahwa jawaban yang diberikan 
berdasarkan alasan yang masuk akal, bukan sekedar menebak secara membabi buta. Kalau hal ini sering dilakukan, maka proses membaca secara kritis akan terjadi dan pemahaman pembelajar adalah pemahaman yang dapat dipertanggungjawabkan. Dengan demikian pembelajar akan berkembang menjadi pembaca yang berhasil dan mandiri.

\section{Kesimpulan}

Dari uraian tersebut di atas dapat disimpulkan bahwa berdasarkan tujuan dan keluasan wilayah kegiatan, ada tiga hakikat membaca: (1) hakikat mikro, yaitu membaca dengan makna terbatas, dengan membaca nyaring sebagai contohnya; (2) hakikat makro, yaitu membaca dengan makna yang sangat luas, misalnya membaca tanda-tanda kebesaran Allah; dan (3) hakikat umum atau sedang (umum dengan pengertian bahwa makna ini merupakan makna yang lebih umum berlaku bagi kegiatan membaca sehari-hari, dan sedang dengan pengertian bahwa cakupan kegiatan yang dilakukan berada di antara keluasan kegiatan dalam hakikat mikro dan makro), misalnya membaca buku yang bermakna berupaya memahami isi buku dengan bantuan pengetahuan dan pengalaman yang dimiliki oleh pembaca.

Sebagai implikasinya, pengajaran membaca sangat ditentukan oleh hakikat mana yang dipergunakan sebagai pedoman. Pembimbing calon qori atau qoriah akan banyak melibatkan pembahasan ejaan dan latihan pengucapan, sedangkan bagi pendakwah. Islam, misalnya, mengajarkan membaca tanda-tanda kebesaran Allah bukan semata-mata mengajarkan lafal atau terjemahan $\mathrm{Al}$ Qur'an melainkan juga membimbing pembelajar untuk memahami apa yang tertulis dalam $\mathrm{Al}$ Qur'an dan teladan kehidupan yang ditunjukkan Nabi dan menghubungkannya dengan ilmu pengetahuan, sejarah kehidupan manusia, gejala alam pada masa lampau dan saat ini, keterbatasan manusia dalam era berkembang pesatnya teknologi, dsb. Keterbatasan manusia inilah yang diharapkan dapat mencapai tujuan membaca: bahwa manusia itu kecil dan yang besar itu Allah. Bagi guru bahasa pengajaran membaca adalah membimbing atau memberi kesempatan kepada siswa untuk berlatih menggunakan strategi dan taktik untuk memahami suatu wacana berdasarkan informasi visual dalam wacana yang dibahas dan informasi non-visual (pengetahuan dan pengalaman siswa dan guru itu sendiri). Kepada pembelajar perlu dilatihkan cara memanfaatkan pengetahuan dan pengalaman secara proporsional untuk membantu pemahaman terhadap wacana-wacana yang dihadapi. Selain itu perlu dilatihkan membaca secara kritis, yang antara lain 
dengan meminta pembelajar mengemukakan alasan tentang jawaban terhadap suatu pertanyaan (apabila suatu wacana disertai dengan pertanyaan bacaan).

\section{DAFTAR PUSTAKA}

Alderson, J. C. \& Urquhart, A. H. (Eds.). (1984). Reading in a Foreign language. London: Longman.

Burnes, D. \& Page, G. (Eds.). (1985). Insight and Strategies for Teaching Reading. Melbourne: Harcourt Brace Jovanovich Group.

Departemen Agama RI. (1984). Al Qur'aan dan Terjemahnya, Juz 1-30. Jakarta: Departemen Agama RI.

Fyfe, R. \& Mitchell, E. (1985). Reading Strategies and Their Assessment. Philadelphia: NFER - Nelson.

Garner, R. (1980). "Monitoring of Understanding: An Investigation of Good and Poor Readers' Awareness of Induced Miscomprehension of Text". Journal of Reading Behavior, 12 (1) 55-63.

Goodman, K. S. (1976). "Reading: A Psycholinguistic Guessing Game". Journal of the Reading Specialist, 4 (126-135).

Goodman, et al. (1987). Language and Thinking in School: $A$ Whole language Curriculum, Thirs Edition. New York: Richard C. Owen.

Harri-Augstein, S. \& Thomas, L. F. (1984). "Conversational Investigations of Reading: The Self-Organized Learner and the Text". In Alderson, J. C. \& Urquhart, A. H. (1984) Reading in a Foreign Language. London: Longman. 
Hood, S. \& Solomon, N. (1985). Focus on Reading: $A$ Handbook for Teachers. Adelaide: National Curriculum Resource Centre.

Irwin, J. W. \& Baker, I. (1989). Promoting Active Reading Comprehension Strategies: A Resource Book for Teachers. Englewood Cliffs, New Jersey: Prentice Hall.

Meyer, V. \& Keefe, D. (1990). Reading for Meaning: Selected Teaching Strategies. Illinois: Scott, Foresman and Company.

Nuttall, C. (1987). Teaching Reading Skills in a Foreign Language. London: Heinemann Educational Books.

Sinclair, J., et al. (Eds.). (1995). Collins Cobuild English Dictionary. London: Harper Collins Publishers.

Smith, F. (1985). Reading. Second Edition. London: Cambridge University Press.

Taylor, I. \& Taylor, M. M. (1983). The Psychology of Reading. New York: Academic Press.

Widdowson, H. G. (1984). Explorations in Applied Linguistics. Oxford: Oxford University Press.

Zuchdi, D. (1991). Keterampilan Membaca dan Faktor-faktor Penghambatnya: Studi Kasus terhadap Mahasiswa Berprestasi Rendah (Laporan Penelitian). IKIP Yogyakarta.

\section{BIODATA (SINGKAT \& LENGKAP) PADA 2 HALAMAN BERIKUT}

\section{BIODATA SINGKAT}

Lahir di Kulon Progo, 27 November 1949. Sarjana Muda IKIP Yogyakarta 1971. Certificate in Marine Hotel Operations, APN Bandung, 1973. Bekerja pada Holland America Line Ltd. 1973-1980. Sarjana IKIP Yogyakarta 1983. 
Staf pengajar Jurdik Bahasa Inggris mulai 1984. Sekjurdik B. Inggris 19871991. Lulus MA TESOL Deakin University Australia 1995. Mulai Maret 1996 mengikuti program $\mathrm{PhD}$ dalam Applied Linguistics (Off Campus) beasiswa Faculty of Arts Deakin University. Karya yang berhubungan dengan tulisan ini a.1.: Kemampuan Membaca (makalah Semiloka UGM, 1989), Reading Aloud (artikel TEFLIN, 1993), Comprehension Strategies (tesis S2, 1995), dan Strategi Pemahaman (penelitian mandiri, 1997). Karya lainnya: Penggunaan Bahasa Indonesia (penelitian latihan, 1990), Permasalahan Listening TOEFL (penelitian latihan, 1991), Empat Book Review tentang grammar, testing, TOFEL, dan writing, dalam tiga terbitan VATME (Victorian Association of TESOL and Multicultural Education, Inc.) Melbourne, Maret 1994, Oktober 1994, dan Mei 1995

\section{BIODATA}

Nama:

\section{SUGIRIN}

Tempat \& tgl. lahir: Kulon Progo, 27 November 1949

Pendidikan:

Lulus Sarjana Muda Bahasa \& Sastra Inggris FKSS IKIP Yogyakarta (1971), Certificate of Marine Hotel Operations APN Bandung (1973), Sarjana Pendidikan Bahasa Inggris FPBS IKIP Yogyakarta (1983), Master of Arts (TESOL) Deakin University, Melbourne, Australia (1995) Sejak Maret 1996 mengikuti program S3 (Off Campus) dengan beasiswa dari Faculty of Arts - Deakin University, Australia.

Pekerjaan/Jabatan: Staf Holland America Line Ltd. (1973-1980), Staf pengajar Jurdik Bahasa Inggris FPBS IKIP Yogyakarta (mulai 1984), Sekjurdik (1987-1991), Lektor Madya mulai Oktober 1993. 
Karya ilmiah/penelitian yang relevan dengan tulisan ini:

1. Penguasaan Kemampuan Membaca Sebagai Tujuan Pengajaran Bahasa Inggris pada Jurusan-jurusan Non-Inggris (Makalah Semiloka Tipologi Latihan, Fakultas Sastra Universitas Gajah Mada, 31 Maret - 1 April 1989)

2. Reading aloud: widely criticized, indispensable to student-teachers of English (artikel dalam TEFLIN Journal - An EFL Journal in Indonesia, Vol 6 Nomer 1 Hal. 113-121, Februari 1993)

3. Comprehension Strategies of EFL Readers (Tesis S2, Juli 1995)

4. Strategi Pemahaman Pembaca Bahasa Inggris Sebagai Bahasa Asing Terhadap Wacana Tulis Berbahasa Inggris (Penelitian mandiri, selesai Maret 1997).

Karya ilmiah/penelitian lainnya:

5. Identifikasi Penggunaan Bahasa Indonesia dalam Mata Kuliah Bidang Studi Jurusan Pendidikan Bahasa Inggris (penelitian sendiri, 1990)

6. Permasalahan Kebahasaan dalam Litening TOEFL yang Dialami Dosen IKIP Yogyakarta Peserta TOEFL (penelitian sendiri, 1991)

7. Using English Grammar: Meaning and Form by Edward Woods \& Nicole McLeod (Book Review diterbitkan dalam VATME Newsletter No. 48, Melbourne, Australia, Maret 1994)

8. Profiles of Learning: The basic Skills Testing Program in New South Wales by G. Masters, et al. (Book Review diterbitkan dalam VATME Newsletter No. 53, Melbourne, Australia, Oktober 1994)

9. Key to Success on the TOEFL by Ronald Feare (Book Review diterbitkan dalam VATME Newsletter No. 53, Melbourne, Oktober 1994)

10. English Essentials: The wouldn't-be-without guide to writing well by $\mathrm{M}$. Fox \& L. Wilkinson (Book Review diterbitkan dalam VATME Newsletter No. 56, Melbourne, Mei 1995).

\section{BIODATA}

Nama:

SUGIRIN

Tempat \& tgl. lahir: Kulon Progo, 27 November 1949 
Pendidikan:

Jabatan Sekarang:

Karya Ilmiah/Penelitian:

1. Penguasaan Kemampuan Membaca Sebagai Tujuan Pengajaran Bahasa Inggris pada Jurusan-jurusan Non-Inggris (Makalah Semiloka Tipologi Latihan, Fakultas Sastra Universitas Gajah Mada, 31 Maret - 1 April 1989)

2. Identifikasi Penggunaan Bahasa Indonesia dalam Mata Kuliah Bidang Studi Jurusan Pendidikan Bahasa Inggris (penelitian sendiri, 1990)

3. Permasalahan Kebahasaan dalam Litening TOEFL yang Dialami Dosen IKIP Yogyakarta Peserta TOEFL (penelitian sendiri, 1991)

4. Reading aloud: widely criticized, indispensable to student-teachers of English (artikel dalam TEFLIN Journal - An EFL Journal in Indonesia, Vol 6 Nomer 1 Hal. 113-121, Februari 1993)

5. Using English Grammar: Meaning and Form by Edward Woods \& Nicole McLeod (Book Review diterbitkan dalam VATME Newsletter No. 48, Melbourne, Australia, Maret 1994)

6. Profiles of Learning: The basic Skills Testing Program in New South Wales by $\mathbf{G}$. Masters, et al. (Book Review diterbitkan dalam VATME Newsletter No. 53, Melbourne, Australia, Oktober 1994)

7. Key to Success on the TOEFL by Ronald Feare (Book Review diterbitkan dalam VATME Newsletter No. 53, Melbourne, Oktober 1994)

8. English Essentials: The wouldn't-be-without guide to writing well by M. Fox \& L. Wilkinson (Book Review diterbitkan dalam VATME Newsletter No. 56, Melbourne, Mei 1995)

9. Comprehension Strategies of EFL Readers (Tesis S2, Juli 1995)

10. Strategi Pemahaman Pembaca Bahasa Inggris Sebagai Bahasa Asing Terhadap Wacana Tulis Berbahasa Inggris (Penelitian mandiri, selesai Maret 1997). 